\title{
NEGATIVE DISCRIMINATION AND ITS PROBLEMS ARISING IN LABOUR LAW RELATIONSHIPS IN EUROPEAN UNION (EU) AND HUNGARIAN LEGAL REGULATIONS
}

\begin{abstract}
This publication discusses the topic of the relationship between legal systems and employment in relation to one of the major obstructive factors: discrimination and unequal treatment. Its topicality is confirmed by the fact that through the occurrence of unequal treatment, considerable sources of tension are encountered currently in the various fields of employment, thinking, inter alia, about of discrimination related to sex, certain individuals, groups, and associated wages and benefits.

The purpose of this short publication is to point out deficiencies in equal treatment through the examination of EU and Hungarian legal regulations, and to formulate suggestions to eliminate them - by, inter alia, amendments of and or additions to regulations, which steps will enable the law to really become a more effective infrastructural tool in the field of employment.
\end{abstract}

\section{Keywords}

discrimination - equal treatment - equal opportunities - labour law relationships

* László Békési, PhD student, Pécs University Faculty of Political Science and Law Doctoral School; laszlo_bekesi@gmail.hu. 


\section{INTRODUCTION}

In order to explore the notion and legal nature of unequal treatment and negative discrimination, another legal category has to be defined first, which is inseparable from discrimination, namely the principle of equal rights. Equal rights (emancipation) is a basic principle with certain content interpenetrating entire legal systems. Equal rights create formal equality, meaning that each individual is equal in relation to the executive power (state). ${ }^{1}$

About the current EU regulation it can be stated that the requirement of the principle of equal rights and the associated equal treatment were formulated in the interest of the EU's economic integration, and were initially declared to enable a more effective enforcement of the four major freedoms (free movement of goods, free movement of capital, freedom of services, and free movement of persons). The Treaty of Rome regulated the principle of equal treatment in three respects; it ordered the prohibition of discrimination between the citizens of the member states, of discrimination between sexes, and discrimination in relation to wages, but since then, these areas have considerably widened. ${ }^{2}$ On the other hand, regarding regulation by the EU, it may be stated that primary law deals rather narrowly with the requirement of equal treatment, for which detailed rules are regulated by secondary legislation (directives).

Instead of prohibition against discrimination, recently, based on directives $^{3}$ passed in 2000 on equal treatment and equal opportunities,

${ }^{1}$ István Kukorelli, Alkotmánytan, (Constitutional Science) Budapest: Osiris Könyvkiadó Kft., 1996, p. 164.

2 Treaty establishing the European Economic Community, articles 6, 48 and 119. (Effective date: Rome, 1 January 1958)

${ }^{3}$ Major EU legislation regarding discrimination and the requirement of equal treatment and the provision of equal opportunities by employers, in the logical order of regulation, is: a) Directive 2000/43/EC of 29 June 2000 implementing the principle of equal treatment between persons irrespective of racial or ethnic origin, O.J. L 180; b) Directive 2000/78/EC of 27 November 2000 establishing a general framework for equal treatment in employment and occupation, O.J. L 303; c) Directive 76/207/EEC of 
the positive side is formulated by labour law, i.e what to do in order to prevent the occurrence of discrimination as it occurred previously. However, it must be admitted that the frequency of occurrence is still on the rise because of the negative regulation. This approach contains the ignoration of the term of discrimination.

Equal opportunities and equal treatment mean that employers must treat each of their employees equally, irrespective of everything else, and ensure opportunities of promotion in an equal manner. Failing to do so results in discrimination which may assume various forms (e.g. direct or indirect, negative or positive discrimination).

A basic rule in connection with the prohibition of discrimination is that discrimination arising from the nature of work is permitted, and, as far as unlawful discrimination is concerned, the burden of proof is reversed meaning that it is not the employee or group of employees who suffered grievance who must prove that they have suffered discrimination-type grievance from the employer, but the employer must prove that their behaviour was not discriminatory.

9 February 1976 on the implementation of the principle of equal treatment for men and women as regards access to employment, vocational training and promotion, and working conditions, O.J. L 039; d) Directive 86/378/EEC of 24 July 1986 on the implementation of equal treatment for men and women in occupational social security schemes, O.J. L 225; e) Directive 75/117/EEC of 10 February 1975 on the approximation of the laws of the Member States relating to the application of the principle of equal pay for men and women, O.J. L 045; f) Directive 76/207/EEC and Recommendation 84/635/EEC of 13 December 1984 on the promotion of positive action for women, O.J. L 331; g) Directive 92/85/EEC of 19 October 1992 on the introduction of measures to encourage improvements in the safety and health at work of pregnant workers and workers who have recently given birth or are breastfeeding, and h) Directive 97/80/EC of 15 December 1997 on the burden of proof in cases of discrimination based on sex, O.J. L 14/6.

In connection with the above directives, Directive 2008/104/EC of the European Parliament and of the Council on temporary agency work, O.J. L 327/9, should also be mentioned, which also contains provisions regulating the requirement of equal treatment (Effective date: Strasbourg, 19 November 2008). 


\section{THE ISSUE OF NEGATIVE DISCRIMINATION IN LABOUR LAW RELATIONS}

\section{LEGAL REGULATION OF NEGATIVE DISCRIMINATION IN THE EU}

In compliance with the provisions of the European Social Charter, the Commission Charter on employees' social rights and article 13 of the Treaty of Rome supplemented by the Treaty of Amsterdam, every EEC member state declares that it will prohibit direct and indirect application of labour law discrimination backed by regulations containing strict sanctions. This is made specific by Directives 76/207/EC, 75/117/EEC requiring the member states to implement the principle of equal treatment in working conditions, vocational training and vocational promotion, as well as in remuneration; and Directive 2000/43/EC expects the member states to require discrimination-free treatment of employees by employers, irrespective of their racial and ethnic status. For all cases of discrimination mentioned herein and committed to the injury of employees, Directive 97/80/EC reverses the burden of proof. In such cases - based on the above - it is the employer who must explain that they have not committed discrimination to the injury of their employee 'accusing' them thereof. Accordingly, all EEC member states, based on reciprocity, and the other Western and Northern European countries (Scandinavia) influenced by the International Labour Organisation (ILO) also prohibit negative discrimination in employment and remuneration applied because of origin, sex, race, religion, ideological, or political conviction, affiliations with representation organisations, ethnic background, marital, maternity, or handicapped status, and recently, homosexual orientation.

The states mentioned above provide freedom of association and prohibit all kinds of negative discrimination associated with union memberships, which provision is also extended by the practice of the EU

4 Tamás Prugberger, György Nádas, Európai és magyar összehasonlító munka- és közszolgálati jog (European and Hungarian comparative labour and public service law), Budapest: Wolters Kluwer CompLex Kiadó Kft., 2014, p. 59. 
Court of Justice with regard to indirect discrimination possibly suffered by certain social groups, mainly women, regarding part-time jobs. ${ }^{5}$

Apart from the directives listed above, Directive 2008/104/EC of the European Parliament and of the Council of 19 November 2008 on temporary agency work should also be mentioned here as a directive which regulates a major section of atypical employment. Article 5 of the Directive details the rules of the basic principle of equal treatment. It may be stated that through its effect it also lessens the defencelessness of temporary agency workers. Of course, there may be counter-arguments enumerated by employers, such as that this makes the extension of employment more expensive and restricts the freedom of agreement between the two actors of the employment relationship. The acceptance of this Directive was preceded by an argument lasting a decade exactly over those issues, and that was the reason it could not be introduced until 2008.

From the viewpoint of editing a legal norm text, a concrete problem can be discovered in this Directive. A closer look reveals that it was by mistake that a provision calling upon the member states to avoid abuses in connection with the application of article 5 and especially to prevent successive assignments designed to circumvent the provisions of this Directive was included in article 5 of the Directive. The effect of this regulation is broader than the enforcement of the basic principle of equal treatment. The 'prevention of successive assignments' as per the text of article 5 (5) implies temporary nature defined as an indispensable element of the notion of temporary agency work, and requires the member states to prevent the circumvention of this provision. ${ }^{6}$

However, it should be highlighted as a major problem that, at EU level, the legal effect of rules concerning equal treatment occurs not comprehensively, but in a layered manner in the member states, and

5 This is confirmed by the labour law rules of the countries listed in volumes I-III of Jura Europae, especially regulations concerning legal institutions under nos.10, 20, 40 and 50 .

${ }^{6}$ István Horváth, Így harmonizálunk mi - Az új Munka Törvénykönyve munkaerökölcsönzésre vonatkozó - az EU-követelményekre is figyelemmel - megállapitott szabályairól, "Magyar munkajog", (The way we harmonize - about the specified rules of the new Labour Code regarding temporary employment agency activites, also considering EU requirements), „Hungarian Labour Law”, Issue 1, 2014, p. 161. 
with not unambiguous results. It is quite understandable that because of the hierarchy of the EU regulations, regulation by primary law is not able to be specific regarding certain areas; to contracts and to legal principles, however, more detailed, relevant definitions could be added in the wordings. Thus, not only expressly, the directives would serve as tools of the enforcement of law.

It would be important for primary law to include not only principles such as the principle of equal pay for equal work ${ }^{7}$, but also concrete definitions such as discrimination-related definitions or the notion of the burden of proof. By this, the directives could focus on setting forth the details of the regulations in a more exact and simple structure.

\section{THE HUNGARIAN CONCEPT OF REGULATING NEGATIVE DISCRIMINATION}

As far as Hungarian regulation is concerned, Directive 2000/43/EC should be mentioned first of all. Article 3 of the Directive specifies its scope, and items A, B and D of section (1) contain relevant, express regulations of a labour law nature. In keeping with the Directive, the Act CXXV of 2003 on equal treatment and the promotion of equal opportunities (hereinafter referred to as 'Ebktv.') makes a distinction between two forms of negative discrimination: direct and indirect negative discrimination.

A regulation as a result of which an individual or a group, owing to their real or presumed situation, property, or characteristics, receives less favourable treatment than another individual or group in a comparable situation receives, received, or would receive, is deemed a direct negative discrimination. A regulation not deemed a direct negative discrimination and apparently meeting the requirements of equal treatment, will be deemed indirect negative discrimination if it puts considerably greater proportions of certain individuals or groups with properties specified in law in a less favourable situation than were, are, or would be other individuals or groups in a comparable situation. ${ }^{8}$

7 Treaty of Rome, article 141 (former article 119) states this right.

8 Section 9 of 'Ebktv.' defines indirect negative discrimination. (Effective date: Budapest, 27 January 2004). 
Section 5 of the former, already overruled, Act XXII of 1992 on the Labour Code (hereinafter referred to as 'Mt.' of 1992) would, after amendment in compliance with the approximation of laws implemented by Act XX of 2003, have separately defined the notion of negative discrimination on the basis of a motion for amendment in compliance with the approximation of laws, the European Social Charter, the action programme thereof and Directive 97/80/EC. It stated that in connection with employment, it is prohibited to negatively discriminate between employees not only owing to their age, sex, marital or handicapped status, maternity, ethnic background, race, origin, their affiliations with representation organisations and their associated activities, but it is also prohibited to apply discrimination against those in part-time jobs, employment with specified-term contracts and contracts for doing a certain job, which forms of flexible employment are becoming more and more frequent in the EU. Also, prohibition against discrimination has been extended to every other circumstance not associated with an employment relationship.

By overruling 'Mt.' of 1992, (entering into force Act I of 2012 on the Labour Code, hereinafter referred to as 'Mt.'), all of the above issues are now regulated, although less precisely, by chapter III, sub-title 'employment' of the operative 'Ebktv.'. ${ }^{9}$ In all the types of discrimination listed above, the burden of proof is reversed in Hungarian law too, i.e. it is the employer who must prove that they have not committed discrimination. ${ }^{10}$

In compliance with Directive 97/80/EC, 'Mt.' of 1992 also defined, as of July 2001, the term „indirect discrimination". A vague allusion is made to this currently by section 8-9 of 'Ebktv.' Apart from that, prior to but similarly to Directive 2000/78/EC, the Hungarian Constitutional Court stated in its resolution no. 35/1994. (VI. 24.) AB that negative discrimination exists when there is no acceptable, reasonable cause for discrimination.

\footnotetext{
${ }^{9}$ Ebktv. sections 21-23.

${ }^{10}$ Csilla Lehoczkiné Kallonay, Az egyenlő bánásmód elve az EU elsődleges és másodlagos jogában, "Egyenlő esélyek és jogharmonizáció", (The principle of equal treatment in the primary and secondary legislation of the EU), "Equal opportunities and approximation of laws", Issue 1, 1997, p. 11-42.
} 
In the course of the judicial application of the law and the legal application activity of Equal Treatment Authority (hereinafter referred to as EBH), a permanent construction system seems to be forming in connection with the prohibition against negative discrimination. This system is somewhat disturbed by the formulation 'other situations' specified in section 8 item $\mathrm{t}$ ) of 'Ebktv.'. Especially in labour law disputes, it often seems to blend with infringement of the requirement of the proper practising of the law. By the formulation 'other situation, property or characteristic', the legislator considerably widened the scope of protected properties. The construction of this notion raises essential labour law issues to be clarified, made more exact in the future.

In this connection, retaliation is also deemed a violation of equal treatment. The type of behaviour causing prejudice to rights, aiming at causing prejudice to rights, or threatening to do so in relation to persons raising objection, initiating proceedings, or contributing to proceedings started owing to the infringment of the requirement of equal treatment, is considered a retaliation. The definition in article 10, section (3) of 'Ebktv.' is an appropriate implementation of article 9 of Directive 2000/43/EC, and the statutory definitions of both harassment and retaliation also satisfy the provisions of Directive 2000/78/EC. This regulation has special importance in legal relationships where the parties are not peers, and one party is subordinated to the other party. This statement leads to the obvious conclusion that the importance of retaliation in employment relationships is indisputable.

However, this issue has been settled in Hungarian law to a certain extent as employees who feel that their employer has violated the requirement of equal treatment, may seek legal remedy in two ways.

Firstly, they may apply to 'EBH' mentioned above and established by 'Ebktv.', which, with a nationwide authority, supervises adherence to the requirement of equal treatment all over the country, and secondly, they may apply directly to the Administrative and Labour Courts. Proceedings before ' $\mathrm{EBH}$ ' are not suitable for judging non-material damage claims: such claims may be enforced exclusively through judicial route by the party having also suffered any injury of their personal rights. The issue is not fully settled, as the process of legal remedy may clearly become more complicated owing to the existence of more than one authority and their powers. 
So currently, regarding Hungarian regulation, the major problem is caused by changes in the regulation environment, the deficiencies of the current regulations, the limited nature of their explanations, and inaccuracies in their wording. It can be stated that prior to the publication of 'Ebktv.', the previous labour law regulation, Mt. of 1992, was right in making efforts in the framework of an independent system to fight off negative discrimination, using its own definitions. Under the current regulations, however, the superficial provisions of laws permanently give rise to disputed situations which are only slightly ameliorated by the effective judicial application of law.

\section{FURTHER REGULATORY PROBLEMS}

Basic definitions/terms, and legal institutions important from the viewpoint of the application of the equal treatment principle are taken over by Hungarian law, and the prohibition against discrimination is declared in the Fundamental Law, the Civil Code, the Labour Code, and 'Ebktv.'. In this regard, Hungarian law is harmonized, and meets in principle the requirement of equal treatment.

At the same time, it has to be stated that a lot remains to be done in the enforcement of equal opportunities policy. The declaration of prohibition against negative discrimination on its own has not been enough to lessen disadvantages even in European states having much more experience and legal culture in this field.

As it was already mentioned above, regarding the requirement of equal treatment, it would be a step toward progress if detailed regulations were specified not only in secondary, but also in primary EU legislation. In this way it could not occur due to hierarchy of legal regulations or a stricter check of texts that faulty provisions were entered by the EU into operative regulations. Reference is made here to Directive 2008/104/EC of the European Parliament and of the Council of 19 November 2008 on temporary agency work, article 5, section (5) regulating the requirement of equal treatment, where abuses concerning the application of this article are mentioned, and namely to the provision calling upon the member states to prevent the circumvention of the provisions of the Directive. It 
would be desirable to suggest the removal of this calling-upon provision at EU level too.

But errors are found on the Hungarian side as well, if a concrete comparison is made regarding this particular provision. Owing to a mistranslation in section 5 (2) of the Directive (instead of permanent contract - continued contract), the principle of equal treatment is more stringent in the Hungarian regulation than required by the EU, which seems to considerably lessen the efficiency of employment, and thereby have an unfavourable effect on the labour market processes and changes in unemployment.

The original English wording of the Directive provides exemption from equal treatment in relation to payment to employees with permanent contracts if they continue to be paid during the time between assignments. On the other hand, the Hungarian translation of the Directive mentions temporary agency workers with continued contracts, which is difficult to construe in legal terms. Because of the unknown term of continued contract in Hungarian law, 'Mt.' does not contain the allowance permitted here.

Speaking of 'Mt.', it should also be mentioned that, as opposed to labour law regulations, 'Ebktv.' settles the requirement of equal treatment and equal opportunities on a wide scale, in a stereotyped manner, extending it beyond labour law to other areas of public administration as well as to the turnover of goods and the use of services, neglecting the peculiarities of these individual fields of law. It also combines procedural law aspects thereof, blending together administrative and judicial proceedings. It mentions at this point the reversing of the burden of proof as the bailout provision for all such proceedings. ${ }^{11}$ Besides, the legislator has taken over numerous equal opportunities and equal treatment provisions of 'Mt.' of 1992 in order to insert them here, depleting the relevant labour law rules. The reason it should not have been done is that this Act is more of a general action programme than labour legislation. Since this has not theoretically become a unified area and institution in Hungarian legislation, the dogmatic side of this principle should be examined in the light of the European and Hungarian legal settlement.

11 Ebktv. section 19. 


\section{SUGGESTIONS TO SOLVE THE PROBLEMS DISCUSSED}

Concerning amendments to the texts of regulations, in article 5 (5) of Directive 2008/104/EK of the European Parliament and of the Council on temporary agency work regulating the requirement of equal treatment, regarding the provision calling upon the member states to prevent the circumvention of the provisions of the Directive, it would be desirable to suggest the removal of this calling-upon provision at EU level too.

The original English wording of the same Directive provides exemption from equal treatment in relation to payment to employees with permanent contracts if they continue to be paid during the time between assignments.

On the other hand, the Hungarian translation of the Directive mentions temporary agency workers with continued contracts, which is difficult to construe in legal terms. Because of the unknown term of continued contract in Hungarian law, 'Mt.' does not contain the allowance permitted here. Therefore, it would be necessary to correct the Hungarian translation of the Directive, along with the relevant provisions of 'Mt.'.

Taking Hungarian regulations, instead of 'Ebktv's less precise provisions, 'Mt.' should, obviously, contain exact provisions concerning both indirect and direct discrimination.

In addition, perhaps it would be necessary to concretize the wording 'other situation' among the protected properties listed in 'Ebktv.', because nowadays the construction of that wording represents the greatest difficulty. In this regard, the opinion no. 288/2/2010. (VI.9) of the Advisory Board of 'EBH' provides guidance, which is also applied by judicial practice. According to the above opinion, the wording 'other situation' should be construed narrowly: it does not cover a situation in which the person concerned finds himself or herself owing to his or her behaviour. Regarding protection, the point is that the cause of disadvantage is an 'essential feature of the personality' and their resultant belonging to a disadvantaged group typically associated with social prejudice. In construing and applying the law, it should never be left out of consideration that the purpose of the rules requiring the enforcement of the principle of equal treatment is always the provision of protection against situations involving prejudice. In order to solve such legal cases 
successfully, it is considered more practical, to include an itemized list in the particular provision for making it clear-cut, which would result in less uncertainty in practice.

Still speaking of regulations, but viewing them in a general context, their effect in everyday life could be boosted using the tools of equal opportunities policy. Using legislation - and thereby applying positive discrimination, interventions in social relations, in the forming thereof should be continued.

Considering the situation in Hungary, it would also be important to have development started in the field of helping handicapped employees, integrating them into the employment system. This field shows a considerable deficiency compared to more developed EU member states. For the time being, we are 'stuck' at the level of eliminating physical obstacles. ${ }^{12}$ The development of the system of institutions provided for those who are handicapped, the improvement, both quantitatively and qualitatively, of a system of tools to promote a 'full life', and the raising of the level of the services (support) system are still formulated as objectives.

12 Réka Bonnyai, Az egyenlő bánásmód elve az Európai Unió jogrendszerében és a magyar jogrendszerben, (The principle of equal treatment in the legal systems of the European Union and Hungary), 2014, p. 51, available at: www.jogiforum.hu/files/publikaciok/bonnyai_ reka_az_egyenlo_banasmod_elve_az_eu_es_magyar_jogrendszerben[jogi_forum].pdf [last access: 23.06.2017]. 